Article

\title{
The Design and Impacts of Individual Sanctions: Evidence From Elites in Côte d'Ivoire and Zimbabwe
}

\author{
Clara Portela ${ }^{1, *}$ and Thijs Van Laer ${ }^{2}$ \\ ${ }^{1}$ Faculty of Law, University of Valencia, Spain \\ ${ }^{2}$ Independent researcher, Belgium \\ *Corresponding author (clara.portela@uv.es)
}

Submitted: 28 July 2021 | Accepted: 11 October 2021 | Published: 26 January 2022

\begin{abstract}
Since the 1990s, sanctions senders like the European Union, the United States, and the United Nations have been imposing visa bans and asset freezes on individuals as a key element of their sanctions packages. Notwithstanding the growing centrality that individual sanctions have acquired in international sanctions practice, little is known about the impact of sanctions listings on designees. Some researchers have scrutinised targeting choices, while others have explored the effects of sanctions on designees. However, no study has yet examined the fit between targeting choices and impacts on designees. First, we interrogate the theory of targeted sanctions to identify the expectations that it generates. Second, we examine the effects on designees and contrast them with the targeting logic of the sender, in a bid to ascertain their fit. Our analysis of the cases of Côte d'Ivoire (2010-2011) and Zimbabwe (2002-2017) benefits from original interview material.
\end{abstract}

\section{Keywords}

Côte d'Ivoire; European Union; impact of sanctions; targeted sanctions; United Nations; Zimbabwe

Issue

This article is part of the issue "Beyond Foreign Policy? EU Sanctions at the Intersection of Development, Trade, and CFSP" edited by Katharina Meissner (University of Vienna) and Clara Portela (University of Valencia).

(C) 2022 by the author(s); licensee Cogitatio (Lisbon, Portugal). This article is licensed under a Creative Commons Attribution 4.0 International License (CC BY).

\section{Introduction}

Sanctions against individuals, i.e., travel bans and asset freezes, have become a regular feature of the international sanctions practice of most senders, including the United Nations Security Council (UNSC), the United States (US) and the European Union (EU). Yet, notwithstanding the frequency of their use, little is known about their impact on the individuals to whom they are applied. Scholars scrutinised the feasibility of targeted sanctions (Tostensen \& Bull, 2002), questioned their ability to prevent humanitarian harm (Gordon, 2019), or discussed their morality (Pattison, 2015) and compatibility with human rights and due process guarantees (Happold, 2016). A few works have examined the impact of sanctions listings on the attitudes and behaviour of designees (Cosgrove, 2005; Eriksson, 2011). However, an examination of the fit between target selection and the actual effects they bring about on individual targets is still missing.

The present article intends to fill that gap. Indications are that anticipated and actual effects on individuals diverge. In their microanalysis of targeting choices by the UNSC, Wallensteen and Grusell (2012) found that most targets were mid-ranking officials, private facilitators, or "middlemen" rather than leaders. Most importantly, they concluded that designation tactics reflected a weak understanding of how individual sanctions would be perceived, which ultimately undermined the credibility of the sanctions. Moreover, their microanalysis hinted at anecdotal evidence of a mismatch between the design of targeted sanctions and their actual impact in the field: Illustratively, their research revealed that a 2004 United Nations (UN) blacklist was mocked locally for featuring 
only three designees who were viewed as peripheral in terms of political power.

The present article investigates the fit between design and impact, focusing on individual sanctions. This article proceeds in four steps. First, it analyses the concept of targeted sanctions as formulated in the context of the "Sanctions Reform Process," a series of expert meetings which specified the notion of targeted sanctions and produced recommendations for their design and implementation: the Swiss-convened Interlaken process, the German-launched Bonn-Berlin process, and the Swedishsponsored Stockholm process (Vines, 2012). A second section reviews research findings regarding the impact of targeted sanctions, while a third section identifies the expectations that these theoretical assumptions generate and explains our methodology. Next, the article examines the actual effects on targets according to their own accounts, after which it contrasts expectations from the targeted logic with the impact of sanctions, in a bid to ascertain their congruence, before the article's conclusion. In order to explore this issue, the sanctions experiences in Côte d'Ivoire (2010-2011) and Zimbabwe (2002-2017) serve as case studies, benefiting from firsthand interview material.

\section{Re-Inventing the Tool: The Rationale of Targeted Sanctions}

The idea of targeted measures was first developed in response to the UNSC's negative experiences with comprehensive trade embargoes. The UNSC became acutely aware of the magnitude of the humanitarian effects of sanctions due to the international outcry provoked by the embargo-induced catastrophe in the Iraq of the mid1990s. As a consequence, the five permanent members of the UNSC (the P-5) issued a "non-paper" stipulating that "any future sanctions regime should be directed to minimise unintended adverse side-effects of sanctions on the most vulnerable segments of targeted countries" and pledging to assess the "short- and long-term humanitarian consequences of sanctions" (UNSC, 1995). This encouraged the development of targeted sanctions, as part of a broader transformation in the design of UN sanctions regimes in the post-Cold War era. By the start of the century, the UNSC usually combined travel bans and asset freezes against individuals, who were often decision-makers (Doxey, 2009). Targeted sanctions became the instrument of choice of the UNSC (Charron et al., 2015).

The principal feature of targeted measures is their discriminatory nature, i.e., their ability to affect specifically those responsible for objectionable actions. The objective is to "apply coercive pressure on transgressing parties-government officials, elites who support them or members of non-governmental entities" (Biersteker, 2001, p. ix). Conversely, this entails avoiding impacts on others or keeping them to a minimum. Then-Secretary General Kofi Annan spoke of "minimis- ing the negative effects of the sanctions on the civilian population and neighbouring and other affected states" (UN, 2000, emphasis added). The EU rapidly embraced targeted sanctions after some of its members had promoted them at the UN (Brzoska, 2003). Its first programmatic document on sanctions policy, entitled Basic Principles on the Use of Restrictive Measures (Council of the EU, 2004), subscribed to this notion, confirming previous practice under the Common Foreign and Security Policy (Portela, 2016). Both the EU and the UN currently impose targeted sanctions, although their measures display varying degrees of discrimination (Biersteker et al., 2016; Wallensteen, 2016).

The intent of hitting the actual wrongdoers goes beyond the mere promotion of justice: "It is designed to hit at the interest of individuals or groups in positions of power directly, rather than the entity they control" (Stenhammar, 2004, p. 150). The disappointing record of comprehensive sanctions in terms of their effectiveness encouraged the refinement of the tool (Brzoska, 2001, p. 10). The hope was that "better targeting of such measures on the individuals responsible... and the elites who benefit from and support them would increase the effectiveness of sanctions" (Biersteker, 2001, p. ix). The assumption that targeted sanctions can be more effective than comprehensive embargoes was predicated on the idea that distinguishing between responsible rulers and the population at large prevented the identification of the population with the targeted leadership, thereby avoiding the "rally-around-the-flag effect" famously formulated by Galtung (1967). In addition, targeted measures could decrease support for those targeted among elites that constitute the power base of rulers. This notion found some elaboration among scholars positing that targeted sanctions are better suited to pressure regime supporters than general embargoes (Kirshner, 1997), weakening autocrats who relied on a small elite or "selectorate" (Brooks, 2002; Park \& Choi, 2020).

However, critics question the viability of targeting sanctions, pointing to the complexity of their implementation and the impossibility of eliminating harm to the population (Gordon, 2019; Tostensen \& Bull, 2002). In this vein, an examination of UN practice suggests that human rights are still more likely to worsen in a country under targeted sanctions compared to countries where sanctions are absent (Carneiro \& Apolinário Jr, 2016). Another criticism concerns the purported lack of efficacy of targeted sanctions. Some experts suggest that targeted measures are less efficacious than comprehensive embargoes. According to Elliott, "more targeted impact also means more limited impact, also for those targeted" (2005, p. 11). Similarly, Cortright and Lopez contend that "where economic and social impact have been greatest, political effects have also been most significant" (2002, p. 8). The Bonn-Berlin process recognised aviation and travel bans as "not much more than a nuisance for targeted elites" (Brzoska, 2001, p. 70). This led some to 
suggest that "options other than smart sanctions should be pursued" (Drezner, 2011, p. 97). Optimistic assessments do not go beyond contending that the efficacy of targeted sanctions is comparable to that of comprehensive embargoes (Biersteker et al., 2016).

\section{What Do We Know About the Impacts of Individual Sanctions?}

The trend towards individualisation observable in sanctions practice has not been matched by a scholarly effort to ascertain the impact of targeted individual sanctions on designees. Despite the growing tendency for sanctions to target individuals, sanctions assessment is routinely conducted with reference to states rather than to the elites targeted, and considers the entire duration of the sanctions regime, without taking into account how the set of measures applied evolve over time. Although some studies have disaggregated country cases into episodes (Biersteker et al., 2016; Eriksson, 2011), most analyses do not systematically evaluate the effects of sanctions on designees.

Scholars highlight the diminished impact of individual sanctions compared to comprehensive sanctions. Elliott examined the impacts of travel and assets sanctions on UN sanctions designees in the post-Cold War era. She found that in some episodes, the political impact is visible, but the economic impact is not. By contrast, where broader sectoral sanctions were applied, evidence of economic as well as political impact is observable in more than half the episodes (Elliott, 2016). Contrary to expectations, she found psychological impacts to be uncommon, even when sanctions publicly and prominently target individuals. Moreover, the psychological impact is never associated with any degree of sanctions effectiveness (Elliott, 2016). According to her findings, stigmatisation was more evident in cases involving armed conflict, where it often eroded political support for targets, than in cases of actors involved in terrorism, repression, or coups d'état (Elliott, 2016).

Cosgrove investigated the effects on two designees under the UN bans on Sierra Leone (1997-2010) and Liberia (2003-2016), two closely related regimes. Mr. Golley, a lawyer from Sierra Leone, confirmed the presence of psychological impact in terms of stigma, as well as significant loss of professional prestige caused by his inclusion in a UN blacklist. At the same time, he did not attribute any changes in his political allegiances resulting from the pressure he came under due to the sanctions (Cosgrove, 2005). Mr Carbah, a former member of the Liberian cabinet, explained that his listing confirmed his loyalty to the Liberian leadership, dissipating any suspicion of proximity with hostile foreign powers. He reported that he did not feel singled out because he viewed the blacklist "as a punishment on the government" to which he belonged (Cosgrove, 2005, p. 220).

Peace researchers Wallensteen and Grusell (2012) analysed data on 450 individuals who featured on eight different UN lists addressing (post-)conflict situations. Their inquiry sheds light on various aspects. Firstly, while designation criteria gained in specificity, the seniority of listed individuals decreased over time. Wallensteen and Grusell criticise the trend of designating persons other than political leaders, given that the lower the individuals are in the decision-making hierarchy, the fewer opportunities there are to influence the course of action that sanctions seek to address. In measuring the ability of designations to bring about target compliance with UNSC demands, Wallensteen and Grusell conclude that the compliance ratio for individually targeted sanctions is not higher than with other sanctions, estimated between $20 \%$ and $34 \%$. Nevertheless, the authors contend that the performance of targeted sanctions could increase with the help of improved targeting policies, ascribing the inefficacy of measures to unsound designee selection.

\section{Expectations, Research Design, and Methodology}

\subsection{Expectations}

Little information is available on the targeting strategies followed by senders, i.e., the calculations that lead to the design of blacklists. Still, certain assumptions can be derived from the logic underlying targeted sanctions outlined above (Wallensteen, 2016). The rationale for targeted sanctions does not explicitly entail assumptions on the anticipated effect on designees; instead, the focus often lies on the impact on populations and elites, who are expected to withdraw their support from the targeted leaderships. In the case of elite members, the expectation may be that designees occupying powerful positions in government may raise the issue of the sanctions for the discussion of remedial action in decisionmaking circles (Wallensteen \& Grusell, 2012).

Once elite members are threatened with a listing, or find themselves listed, they can feel compelled to sever links with more senior targets or switch sides to forestall or reverse designation. Recent scholarship highlights the power of threats, which are often believed to be more effective than imposed measures (Hovi et al., 2005; Whang et al., 2013). Finding themselves deprived of the backing of erstwhile supporters and facing increased unpopularity, leaders may align policy with sender preferences, which, in our cases, entail organising free and fair elections or stepping down, as this option is preferable to being unseated by force. There are, however, no reasons to believe that designations are meant to modify the political persuasion of the targets. Instead, targeted actors are expected to behave strategically.

Key to the operation of targeted sanctions are the effects on group dynamics. In 2004, the panel of experts monitoring the sanctions on Côte d'Ivoire recommended avoiding targeting an entire group in order to prevent them from bonding in opposition against the sender. Accordingly, initially modest listings that can be escalated 
subsequently are often preferred. Following this logic, we can only expect blacklists to hinder group cohesion if designations do not extend to entire groups.

Thus, we put forward the following set of expectations:

H1: Designations have disruptive effects on the political and professional activity of targets, and sometimes on their subjective wellbeing, but fail to modify their political views and conduct.

$\mathrm{H} 2$ : The designation of high-ranking officials promotes the discussion of possible remedial action in decision-making circles, but is susceptible of strengthening elite cohesion concurrently.

The aim of our research is to broaden our knowledge of the effects of individual sanctions by illuminating the dynamics at play. By contrast, we do not intend to ascertain whether the measures contributed to the outcome desired by the senders, a complex question that exceeds the scope of this article.

\subsection{Case-Study Selection}

The case studies selected for our research are two governance crises in sub-Saharan Africa, the world region with the highest density of international sanctions (Charron, 2013): the sanctions imposed on Côte d'Ivoire following the controversial presidential elections of November 2010, and those on Zimbabwe triggered by the land reform and electoral crisis of 2002. These episodes were selected because they correspond to the type of crisis that attracts EU and US sanctions, characterised by the presence of civil strife and democratic backsliding (Dipama \& Dal, 2015). Importantly, they were both at the receiving end of EU sanctions: in Côte d'Ivoire, complementing UN restrictions, and in Zimbabwe, acting in concert with the US and other Western countries. While individual sanctions were a significant component in their respective sanctions packages, they were accompanied by broader restrictions of an economic or financial nature as well as other international measures.

Since the blacklists on both countries reached record numbers, the abundance of listings increased the likelihood of locating designees willing to share their experiences in an interview. At the same time, important differences set these cases apart, making their exploration intriguing. Of special note, Côte d'Ivoire experienced a wide array of sanctions by multiple senders: the UN, the EU, the US, and regional organisations, which proved unusually active (Bellamy \& Williams, 2011), providing a case of interaction between UN, regional, and extra-regional measures (Piccolino, 2012), in addition to military force. In contrast, the protracted Western sanctions enacted on Harare after the electoral crisis of 2002 lacked regional and UN support (Giumelli \& Krulis, 2012; Grebe, 2010).

\subsection{Methodology}

The lists for Côte d'Ivoire and Zimbabwe included numerous politicians who were no longer in power and whose designations under UN or EU sanctions regimes had elapsed, although US listings remained in force for some Zimbabweans. This elite profile is more accessible to researchers than other frequent designee types such as commanders of armed groups, heads of the security services, or private facilitators such as arms dealers, who would be almost impossible to reach, let alone interview. Accessibility is of paramount importance given that our research aimed at collecting data from multiple designees. Data was collected in the course of fieldwork in Côte d'Ivoire and Zimbabwe in 2018. The sample selection was guided by pragmatism: Contacts in Côte d'Ivoire and Zimbabwe were approached with the intention of locating former designees. Those who could be located and agreed to be interviewed were asked to facilitate further contacts with fellow designees, as they were integrated in identical networks. The sizable number of listings, combined with the facilitation role of some designees or their associates, yielded a number of five to six interviews in each country. We can thus rely on first-hand data.

Cosgrove's original methodological approach (2005), later replicated by Eriksson (2011), was adopted: Semistructured, in-depth interviews were conducted with designees with the help of an interview guide reproduced in Annex II of the Supplementary File. Due to the delicate nature of the issue under study, the sample selection followed a pragmatic rationale: Not all designees who could be located agreed to be interviewed. Admittedly, this approach is susceptible of creating a selection bias. Because the elite members self-select into respondents, a specific profile of designees might have been attracted, such as those who lacked significant influence over government decisions (as they indeed claimed) or wished to protest about their victimisation. Cognizant of this selection bias, we have taken it into account in our assessment. Yet the stigma associated with designations, coupled with the voluntary nature of participation in the interviews, makes it difficult to contemplate alternatives to the approach adopted.

The interview guide focused on questions that relate to the key elements of targeted sanctions, as well as specific risks associated with their use, as identified in existing literature and outlined above. They can be clustered around several issues: (a) the target's reaction to the (threat of) sanctions; (b) the effects of the designation in terms of restricting the targets' professional and personal activity, as well as psychological effects; (c) consequences of these effects on political behaviour and views of the targets; and (d) impact on group cohesion (see Annex II in the Supplementary File). The analysis of the interview material is articulated around our two main hypotheses, the first of which centres around the 
individual level, while the second focuses on the collective level.

The semi-structured format of the interview and a flexible use of the interview guide allowed for a dynamic exchange with interviewees in which additional questions could be asked (or skipped) to delve into the most intriguing responses, yielding rich, sometimes unexpected testimonies. Interviews were conducted in French in Côte d'Ivoire, where it is the official language, and in English in Zimbabwe, where it is the lingua franca, to allow respondents maximum ease of expression. Translations from French are the authors'.

\section{Sanctions in Governance Crises}

\subsection{The Côte d'Ivoire Crisis}

More than a decade of instability, which saw the application of sanctions by the UN and the EU, preceded the 2010-2011 crisis in Côte d'Ivoire (Bellamy \& Williams, 2011). In 2000, an uprising had brought Laurent Gbagbo to power, after General Robert Guéï, who had promised a transition after a 1999 coup, failed to step down. Yet, in 2002, a rebellion contesting Gbagbo's rule erupted, dividing the country into a rebel-controlled north and a government-controlled south. A UN peacekeeping force was deployed to separate the parties, soon reinforced by military forces dispatched by the former colonial power, France. Several peace agreements failed to be implemented (O'Bannon, 2012), which led the UNSC to impose sanctions in 2004 (UNSC, 2004). Presidential elections were finally called in November 2010, pitting President Gbagbo against Alassane Ouattara, who claimed victory based on provisional results proclaimed by the electoral commission, certified by the UN. Gbagbo lodged an appeal to the Constitutional Council, which annulled the provisional results and proclaimed his victory with $51.5 \%$ of the votes (Cook, 2011). Most international actors, however, called on Gbagbo to step down. The African Union and the Economic Community of West African States (ECOWAS) suspended the membership of Côte d'Ivoire (African Union, 2010) and dispatched mediators, but even ECOWAS' threat of a military intervention failed to persuade Gbagbo to step down (Cook, 2011). In a bold step, the West African Economic and Monetary Union (UEMOA) granted Ouattara authority over UEMOA-related transactions conducted via the Central Bank of West African States (BCEAO) in late December 2010 (UEMOA, 2010).

The UN, the EU, and the US enacted sanctions in response to the post-electoral crisis. The US imposed a visa ban on members of Gbagbo's regime in December 2010, which it expanded in January 2011, barring designees from financial transactions (US Treasury, 2011). The EU followed suit, imposing a visa ban on Gbagbo and 18 individuals for "obstructing the process of peace and national reconciliation, and... jeopardising the proper outcome of the electoral process"
(Council Decision 2010/801/CFSP of 22 December 2010, 2010). As the situation deteriorated, in January 2011 the EU extended its blacklist to 85 individuals and 11 entities, including the harbours of Abidjan and San Pedro (Council Decision 2011/18/CFSP of 14 January 2011, 2011). In March 2011, the UNSC listed five individuals, in addition to the three individuals listed since 2004, threatening further sanctions. The situation escalated into a military conflict as Ouattara formed an armed movement, the Forces Républicaines de Côte d'lvoire (FRCI). The UN mission, together with French forces, proved decisive in breaking the deadlock. On 11 April 2011, FRCl troops backed by UN forces arrested Gbagbo and installed Ouattara as president (Abatan \& Spies, 2016). Gbagbo and militia leader Charles Blé Goudé were handed over to the International Criminal Court, which acquitted them in 2019. At Ouattara's request, sanctions were gradually eased until their complete lifting in 2016 (Council Decision (CFSP) 2016/917 of 9 June 2016, 2016; The White House, 2016; UN, 2016).

\subsection{The Zimbabwe Crisis}

Sanctions against the Zimbabwean leadership were imposed in 2001-2002. Their origins lie in a violent land expropriation campaign of white farmers, followed by the crisis surrounding the 2002 parliamentary elections which saw the harassment of the opposition and the rejection of international observers. In 2001, the US imposed restrictions on multilateral financing, followed by financial sanctions and travel bans against selected individuals and entities, a ban on defence business and a development aid freeze (US Congress, 2001). In February 2002, the EU suspended aid and enacted an arms embargo along with a visa ban and assets freeze against President Mugabe and members of his party, the Zimbabwe African National Union-Patriotic Front (ZANU-PF). Australia, Canada, and others followed suit, but neither the UN nor African organisations enacted sanctions. Meanwhile, in parallel to the political crisis, a major economic crisis turned Zimbabwe into the world's fastest shrinking economy. In the following years, the EU gradually expanded the number of individuals on its list, which reached a peak in January 2009 with 203 individuals and 40 entities.

Following the signing of the Global Political Agreement, under which President Mugabe shared power with two opposition leaders, the EU started a partial easing of sanctions. In February 2011, Brussels de-listed 35 individuals in recognition of progress while leaving on the list 163 people and 31 businesses for human rights abuses and undermining democracy and rule of law (Council Decision 2011/101/CFSP of 15 February 2011, 2011). In 2013, the EU suspended sanctions on 81 individuals in response to the peaceful vote to approve a new constitution, and in 2014, Brussels suspended measures against all individuals and entities, except for Mugabe, his wife, and Zimbabwe 
Defence Industries (Council Decision 2013/160/CFSP of 27 March 2013, 2013; Council Decision 2014/98/CFSP of 17 February 2014, 2014). In November 2017, Mugabe was forced to resign after the military took control of the country, and passed away in September 2019. Currently, EU sanctions remain in force against Zimbabwe Defence Industries, while those against four remaining designees are suspended. The US maintains sanctions on 38 entities and 25 individuals.

\section{Impacts on Target Elites}

We now review our interview material with reference to our hypotheses. Eleven (former) designees were interviewed: six Ivoirians and five Zimbabweans. Tables 1 and 2 display their elite groups as well as the entities that designated them, respectively. A summary overview of selected responses is displayed in Annex III of the Supplementary File.

Finding 1: Designations had disruptive effects on the political and professional activity of the targets, and sometimes on their subjective wellbeing, but failed to modify their political views.

The travel bans inconvenienced some targets in their personal as well as professional capacity. "Not being able to travel is a big political handicap," stated a respondent from Côte d'Ivoire: "There was no way of evading the sanctions. One cannot make a trip clandestinely....We were in need of a repositioning, of taking a new impetus; thus, we needed to travel" (C1). Particularly affected were those who were already under UN sanctions, given the universal reach of UN bans. Some pointed to the mutually reinforcing effects of travel bans and freezing of assets, as a senior Ivorian politician indicated: "One cannot travel with an asset freeze; this is the most penalising measure" (C1). The obstructive effect of the restrictions is most visible in the statement by an Ivorian designee, who claimed that had there been no travel bans, "we could have exported the fight to the sub-regional level" (C4).

In the Ivorian case, the restrictive effect of sanctions was magnified by the high level of regional co-operation and by the continuation of the asset freezes by the Ouattara government after it took control. The West African region was unusually active in enforcing international restrictions and in imposing its own measures, notably in the form of ECOWAS membership suspension and BCEAO's financial measures. "The... asset freeze affected me a lot... my children did not attend school.... How are we meant to pay rent?" (C2), one of those affected said. Others complained: "I could not receive my salary, this disrupted my life" (C6); "my accounts here were blocked... this complicated my life" (C5). Several individuals reported that they were unaware of why they had been listed or what they could do to try to be taken off the list. One respondent claimed: "I was never notified I was under sanctions. I saw it in the newspapers" (C2). A senior pro-Gbagbo journalist stated: "I was not aware that I was on the EU's list" (C6).

While most respondents maintained that they were not psychologically affected by the sanctions, some complained about severe impacts. A former pro-Gbagbo youth leader admitted: "I was shocked. I felt revolted and not understood" (C4). Zimbabwean interviewees characterised the experience as "really traumatic" (Z2) or "devastating....You can't be the same anymore....All your hopes are dashed. You fall into debt, your entity [business] cannot perform" (Z5). Those who saw family members affected or owned companies suffered most from the sanctions, as did those who conducted professional activities which involved the senders.

In line with our expectations, none of the respondents reported having modified their political views because of the sanctions. On the contrary, they insisted on the lack of legitimacy of the measures. An Ivorian politician summarises: "There was a rebellion attacking us... they took up arms. They were not told [off], it was on us... they imposed sanctions" (C4). Zimbabwean respondents accused political adversaries of calling for the imposition of sanctions and suggesting designations to the senders (Z1-Z3). By contrast, respondents displayed a proclivity to contestation of both the sanctions and the specific grounds for which they were personally targeted, criticising what they perceived as the onesided character of the sanctions. In the words of one respondent: "There was a flavour of partiality [to the

Table 1. Distribution of respondents by profile.

\begin{tabular}{lcc}
\hline Example & Ivorian targets & Zimbabwean targets \\
\hline Leaders & 1 & 1 \\
Administrators & 2 & 2 \\
Supporters & 3 & 2 \\
\hline
\end{tabular}

Table 2. Distribution of respondents by designation sender.

\begin{tabular}{lll}
\hline UN & EU & US \\
\hline $\mathrm{C} 1, \mathrm{C} 4$ & $\mathrm{C} 2, \mathrm{C} 3, \mathrm{C} 5, \mathrm{C} 6, \mathrm{Z1}-\mathrm{Z5}$ & $\mathrm{Z1-Z5}$ \\
\hline
\end{tabular}


sanctions], of side-taking by the international community. That created frustration" (C1). In Côte d'Ivoire, the EU only sanctioned the pro-Gbagbo camp, although inquiries concluded that serious human rights violations, some possibly amounting to international crimes, were committed by both sides to the Ivorian conflict (Human Rights Council, 2011): "There was never an investigation of Ouattara [who] also committed crimes against humanity," a former pro-Gbagbo official claimed (C2). There was also contestation of the international rejection of the constitutional court's decision, as one interviewee stated: "The international community should not decide. Conformity with the law cannot represent a problem!" (C2). The grounds and procedure for blacklisting were rebutted by several. One of the designees complained: "Europe is the continent of law, but they never gave me the right of reply" (C2). A pro-Gbagbo newspaper editor listed by the EU for incitement to hatred and violence said: "I asked [about the reasons for the sanctions], but I was not given any explanation" (C6).

When respondents admitted having had a change of heart, this was attributed to other reasons. An opposition leader who opted for moderation after Gbagbo was arrested indicated that "sanctions do not have an effect on ideology. That did not dictate my line of action; the country's situation did" (C1); a sanctioned youth leader claimed: "They did not have any impact on my actions" (C4); and a former minister even said: "It hardened my position" (C6). Yet some respondents did report having changed their political views, deepening their mistrust of international institutions and Western countries. Respondents in Côte d'Ivoire often refer to the French leadership rather than to the EU, reflecting Paris' prominence with regard to its former colony. Statements included: "It was France that decided" (C2); "it was France, Sarkozy and his friends who were behind the sanctions" (C6); "at the UN, Côte d'Ivoire is France's preserve" (C4). According to one respondent, experiencing sanctions changed his perspective on the EU and the UN: "One should not be under any illusion about how they advance their interests. One must play politics in order to avoid being targeted" (C1). Former Ivoirian designees claimed that "the international community discredited itself" (C3) or: "I did not believe the UN was capable of such injustice" (C4). For their part, Zimbabweans under EU and US sanctions said: "I learned more about how imperialism works" (Z1) or "the US is still a colony of Britain" (Z4).

Finding 2: There is no evidence that designations of high-ranking officials promoted the discussion of possible remedial action in decision-making circles; instead, they strengthened elite cohesion.

There was a clear recognition that sanctions played a role among members of the political elite: "Of course we took into account the sanctions....They had an impact, whether you like it or not," a well-known politician in Côte d'Ivoire explained (C1). However, respondents invariably claimed that changes in policy remained beyond their control, despite the fact that they held positions of responsibility within government or the ruling party. A former party stalwart claimed that sanctions were not discussed in his (ruling) party: "There was no change in position in ZANU-PF [because of the sanctions]. We never discussed it" (Z3). It could be ventured that rulers under sanctions might centralise all political authority in themselves, so that any political decision might be taken by the leader alone. Yet the statement by a former minister who was interviewed points to the dilution of responsibility in the context of collective decisionmaking: "As a minister, you cannot take decisions outside the government. You go by what the majority decides. You are member of a collective" (Z1). For their part, former deputy ministers interviewed in Zimbabwe affirmed that they did not partake in government decisions. One of them said: "All I had to do was implement policies made by the political party or parliament. I had no capacity to influence decisions as a deputy minister. I did not attend cabinet meetings" (Z2). Similarly, another former deputy minister claimed: "I was not in a position to change anything. If you are on a plane, you depend on the cabin crew" (Z4). This can be explained by a selection bias embedded in our sample of voluntary interviews: Only individuals without responsibility in grave human rights abuses might have agreed to be interviewed, while others held back.

Some bonding due to sanctions was reported in both Zimbabwe and Côte d'Ivoire, where an interview explained: "In a certain environment, sanctions had a political meaning. Some carry their designation with pride, as a symbol of their fight" (C1). A former Zimbabwean minister claimed that while sanctions had a negative impact, they "did bring people together, those on the list. There was a sense of belonging, we forged ahead" (Z5). In Côte d'Ivoire, the de-listing of moderate opponents was used to discredit them, as one of those affected stated: "Some wanted to instrumentalise the sanctions against normalisation. They interpreted the lifting of sanctions as complicity" (C1).

Separately from group cohesion among decisionmaking elites, several respondents explained that being under sanctions increased social bonding with the networks they relied on. One of them said: "I experienced plenty of sympathy, plenty of support-this increased my popularity" (C4). A women's leader of Gbagbo's political party said that "it was thanks to the solidarity of certain people that I did not have problems" (C5). In the same vein, a pro-Gbagbo publicist indicated: "My acquaintances did not accept this situation; they helped me survive" (C6). Some used the sanctions to ramp up support among their electorate, as a former Zimbabwean deputy minister and member of parliament explained: " 'Down with the sanctions' became a chorus" (Z2). Nevertheless, the high number of designations dilutes the impact of the measures, in line with the warning by the UN panel of 
experts mentioned at the outset. Respondents pointed to the large number of designees when justifying the lack of impact of the measures on their political orientation"we were very many under sanctions," said a leader of the Ivorian Popular Front (C5)-or their designation: "The whole cabinet was sanctioned," according to a Zimbabwean respondent (Z4). A former Zimbabwean minister went as far as stating: "If I had been left out, I would have felt not recognised for my efforts in the liberation struggle" (Z3).

\section{Conclusions}

Our exploration confirms earlier insights about the effects of sanctions on elite members. The very fact that some individuals challenged their listing in court indicates that designations inconvenience targets: Zimbabwean and Ivoirian designees on the EU sanctions list, including some of our respondents, lodged complaints at the European Court of Justice, requesting the annulment of the sanctions (e.g., Gbagbo and others $v$. Council, 2013). Our interviewees reported at least some level of disruption of their political and professional activity, as well as of their personal life and sometimes even subjective wellbeing, as a statement from a respondent in Harare illustrated: "It changed me; made me more hostile" (Z2).

Yet, and in line with previous findings, while respondents admitted having experienced some level of inconvenience in their personal or political activity, this did not translate into any modification of the leadership's policy or any meaningful discussion of possible remedial action in decision-making circles. Although one can only speculate as to the reasons that prevented such deliberations, two insights emerge from our exploration. Firstly, there was a lack of awareness among the designees about their own listings; most of them claimed to have learnt about their designation from newspapers, or even not to have learnt about it until the interview. Several said they did not know why they had been listed, which limited the possibility for them to comply. By the same token, they never established communication with sender entities to discuss de-listing, as a former member of government in Zimbabwe said: "I was never in touch with EU or the US. What for? I would meet only people on our side: China, Russia, Cuba and developing countries" (Z1). Secondly, there is some evidence that long blacklists foster cohesion among elites. This was particularly visible in EU and US blacklists: Even though these senders share the UN preference for an initially small number of designations, their blacklists grew quickly in both cases under study, as new waves of designations followed in close succession, mirroring the escalation of the political crises. Soon, the initially short blacklists encompassed virtually the entire ruling political elite. There are indications that this fostered cohesion among members of the political elite, and even strengthened solidarity bonds with their entourage, while it prevented the emergence of other groups in the ruling elite-themselves not under sanctions-who could have counterbalanced blacklisted hardliners. This bonding feeds on feelings of spite among those targeted, who invariably contested the legitimacy of the sanctions, rebutting the grounds for listings and accusing the senders of partiality.

Assuming that these reactions are genuine-as we do-they show the operation of individual sanctions in a new light. Firstly, several designees reported being unaware of their listings, which implies that, in most cases, senders did not make use of threats prior to the actual designations. This seems counterintuitive, as threats of sanctions have often proved more successful than sanctions imposition itself (Hovi et al., 2005; Whang et al., 2013). The Council of the EU is legally bound to "communicate its decision, including the grounds for listing, to the person or entity concerned, either directly... or through the publication of a notice" (Council Decision 2010/801/CFSP of 22 December 2010, 2010). The notices for our respondents were only published in the Official Journal of the EU and did not reach the designees. Lack of awareness of the listings and of the corrective action expected to obtain de-listing failed to afford designees the information that might have compelled them to negotiate either remedial action or their removal from the blacklist (International Crisis Group, 2012). None of the designees mentioned that a possible accommodation with the senders was discussed, either individually or in collective circles, to promote the removal or the easing of the measures. Instead, designees were left with the perception that blacklisting is merely a form of punishment, as evidenced in their discourse- "punishment does not change you" (Z5); "it was just a blanket... collective punishment" (Z4)-replete with allusions to criminal justice: "It is like being accused of a crime you have not committed" (Z4); "nothing was proved" (C4). Designees did not approach senders unless they fell out with other members of the leadership. As a result, the lack of communication between sender entities and designees leaves us in the dark as to whether individual sanctions could have facilitated a negotiated resolution of the crises.

\section{Acknowledgments}

We thank Katharina Meissner, Yuleng Zeng, the participants of the ECPR Joint Session "Designing Sanctions: The European Union in Regional and International Affairs" held from 17 to 28 May 2021, and two anonymous reviewers for valuable comments on earlier versions of this article. Interview material was collected by Thijs Van Laer, who wishes to thank the respondents for their valuable time and those who supported the research trips to Abidjan and Harare. This article is part of the research project "Seguridad Pública, Seguridad Privada y Derechos Fundamentales" RTI2018-098405-B-100, funded by Ministerio de Ciencia, Innovación y Universidades in Spain. Clara Portela 
gratefully acknowledges the grant received from this project to support research for this article at the Institut d'Etudes Politiques in Paris (France).

\section{Conflict of Interests}

The authors declare no conflict of interests.

\section{Supplementary Material}

Supplementary material for this article is available online in the format provided by the author (unedited).

\section{References}

Abatan, E., \& Spies, Y. (2016). African solutions to African problems? The AU, R2P and Côte d'Ivoire. South African Journal of International Affairs, 23(1), 21-38.

African Union. (2010). Political and Security Council communiqué, 9 December 2010 (PSC/PR/COMM.1 (CCLII)).

Bellamy, A., \& Williams, P. (2011). The new politics of protection. International Affairs, 87(4), 825-850.

Biersteker, T. (Ed.). (2001). Targeted financial sanctions: A manual for design and implementationContributions from the Interlaken process. Watson Institute for International Studies.

Biersteker, T., Eckert, S., \& Tourinho, M. (Eds.). (2016). Targeted sanctions. The impacts and effectiveness of UN action. Cambridge University Press.

Brooks, R. (2002). Sanctions and regime type: What works, and when. Security Studies, 11(4), 1-50.

Brzoska, M. (Ed.). (2001). Design and implementation of arms embargoes and travel and aviation related sanctions. Results of the "Bonn-Berlin process." Bonn International Centre for Conversion.

Brzoska, M. (2003). From dumb to smart? Recent reforms of UN sanctions. Global Governance, 9(4), 519-535.

Carneiro, C. L., \& Apolinário Jr, L. (2016). Targeted versus conventional economic sanctions: What is at stake for human rights? International Interactions, 42(4), 565-589.

Charron, A. (2013). Sanctions and Africa. In J. Boulden (Ed.), Responding to conflict in Africa (pp. 77-98). Palgrave.

Charron, A., Giumelli, F., \& Portela, C. (2015). Introduction: The United Nations and targeted sanctions. International Affairs, 91(6), 1335-1337.

Cook, N. (2011). Côte d'Ivoire post-Gbagbo: Crisis recovery. Congressional Research Services.

Cortright, D., \& Lopez, G. (2002). Sanctions and the search for security. Lynne Reiner.

Cosgrove, E. (2005). Examining targeted sanctions. Are travel bans effective? In P. Wallensteen \& C. Staibano (Eds.), International sanctions: Between words and wars in the global system (pp. 207-228). Frank Cass.

Council Decision 2010/801/CFSP of 22 December 2010 amending Council Decision 2010/656/CFSP renewing the restrictive measures against Côte d'Ivoire. (2010). Official Journal of the European Union, L 341/45.

Council Decision 2011/18/CFSP of 14 January 2011 amending Council Decision 2010/656/CFSP renewing the restrictive measures against Côte d'Ivoire. (2011). Official Journal of the European Union, L 11/36.

Council Decision 2011/101/CFSP of 15 February 2011 concerning restrictive measures against Zimbabwe. (2011). Official Journal of the European Union, L 42/6.

Council Decision 2013/160/CFSP of 27 March 2013 amending Decision 2011/101/CFSP concerning restrictive measures against Zimbabwe. (2013). Official Journal of the European Union, L 90/95.

Council Decision 2014/98/CFSP of 17 February 2014 amending Decision 2011/101/CFSP concerning restrictive measures against Zimbabwe. (2014). Official Journal of the European Union, L 50/20.

Council Decision (CFSP) 2016/917 of 9 June 2016 repealing Decision 2010/656/CFSP renewing the restrictive measures against Côte d'Ivoire. (2016). Official Journal of the European Union, L 153/38.

Council of the EU. (2004). Basic principles on the use of restrictive measures (sanctions), 7 June 2004.

Dipama, S., \& Dal, E. P. (2015). The effectiveness of political conditionality as an instrument of democracy promotion by the EU: Case studies of Zimbabwe, Ivory Coast and Niger. Perceptions, 20(1), 109-132.

Doxey, M. (2009). Reflections on the sanctions decade and beyond. International Journal, 64(2), 539-549.

Drezner, D. (2011). Sanctions sometimes smart: Targeted sanctions in theory and practice. International Studies Review, 13(1), 96-108.

Elliott, K. A. (2005). Trends in economic sanctions policy. In P. Wallensteen \& C. Staibano (Eds.), International sanctions: Between words and wars in the global system (pp. 3-14). Frank Cass.

Elliott, K. A. (2016). The impacts of United Nations targeted sanctions. In T. Biersteker, S. Eckert, \& M. Tourinho (Eds.), Targeted sanctions: The impacts and effectiveness of United Nations action (pp. 172-189). Cambridge University Press.

Eriksson, M. (2011). Targeting peace. Understanding UN and EU targeted sanctions. Ashgate.

Galtung, J. (1967). On the effects of international economic sanctions: With examples from the case of Rhodesia. World Politics, 19(3), 378-416.

Gbagbo and others v. Council, Joined Cases C-478/11 P to $\mathrm{C}-482 / 11 \mathrm{P}$ (2013).

Giumelli, F., \& Krulis, K. (2012). Understanding the success of targeted sanctions. The EU in Zimbabwe. Central European Journal of International and Security Studies, 6(2), 168-194.

Gordon, J. (2019). The hidden power of the new economic sanctions. Current History, 118(804), 3-10.

Grebe, J. (2010). And they are still targeting: Assessing the effectiveness of targeted sanctions against Zimbabwe. Africa Spectrum, 45(1), 3-29.

Happold, M. (2016). Targeted sanctions and human 
rights. In M. Happold \& P. Eden (Eds.), Economic sanctions and international law (pp. 87-111). Hart.

Hovi, J., Huseby, R., \& Sprinz, D. (2005). When do imposed economic sanctions work? World Politics, 57(4), 479-499.

Human Rights Council. (2011). Report of the independent international commission of inquiry on Côte d'Ivoire (A/HRC/17/48).

International Crisis Group. (2012). Zimbabwe's sanctions standoff.

Kirshner, J. (1997). The microfoundations of economic sanctions. Security Studies, 6(3), 32-64.

O'Bannon, B. (2012). No war-No peace: The "postconflict" environment in Côte d'lvoire. UNICEF Thailand.

Park, J., \& Choi, H. J. (2020). Are smart sanctions smart enough? An inquiry into when leaders oppress civilians under UN targeted sanctions. International Political Science Review, 84(3), 849-872.

Pattison, J. (2015). The morality of sanctions. Social Philosophy and Policy, 32(1), 192-215.

Piccolino, G. (2012). David against Goliath in Côte d'Ivoire? Laurent Gbagbo's war against global governance. African Affairs, 111(442), 1-23.

Portela, C. (2016). Are EU sanctions "targeted"? Cambridge Review of International Affairs, 29(3), 912-929.

Stenhammar, F. (2004). UN smart sanctions. Political reality and international law. In D. Amneus \& K. Svanberg-Torpman (Eds.), Peace and security. Current challenges in international law (pp. 145-75). Studentlitteratur.

The White House. (2016). Termination of emergency with respect to the situation in or in relation to Côte d'Ivoire (Executive Order 13739).

Tostensen, A., \& Bull, B. (2002). Are smart sanctions feasible? World Politics, 54(3), 373-403.
United Nations. (2000). Report of the Secretary-General on the work of the organisation (Doc. A/55/1).

United Nations Security Council. (1995). Letter from the Permanent Representatives of China, France, the Russian Federation, the U.S. and the UK to the United Nations addressed to the President of the Security Council (S/1995/300).

United Nations Security Council. (2004). S/RES/1572.

United Nations Security Council. (2016). S/RES/2283.

US Congress. (2001). Zimbabwe democracy and economic recovery act $S .494$.

US Treasury. (2011, January 6). Treasury targets former Côte d'Ivoire President Laurent Gbagbo and members of his inner circle [Press release]. https://www.treasury.gov/press-center/pressreleases/Pages/tg1017.aspx

Vines, A. (2012). The effectiveness of UN and EU sanctions: Lessons for the twenty-first century. International Affairs, 88(4), 867-877.

Wallensteen, P. (2016). Institutional learning in targeted sanctions. In T. Biersteker, S. Eckert, \& M. Tourinho (Eds.), Targeted sanctions. The impacts and effectiveness of UN action (pp. 248-264). Cambridge University Press.

Wallensteen, P., \& Grusell, H. (2012). Targeting the right targets? The UN use of individual sanctions. Global Governance, 18(2), 207-230.

West African Economic and Monetary Union. (2010, December 23). Communiqué de presse de la session extraordinaire du Conseil des Ministres de I'UEMOA [Press release of the extraordinary session of the Council of Ministers of UEMOA] [Press release]. https://www.bceao.int/sites/default/files/inlinefiles/Communique_de_Presse_CME_Bissau0001.pdf

Whang, T., Mclean, E., \& Kuberski, D. (2013). Coercion, information, and the success of sanction threats. American Journal of Political Science, 57(1), 65-81.

\section{About the Authors}

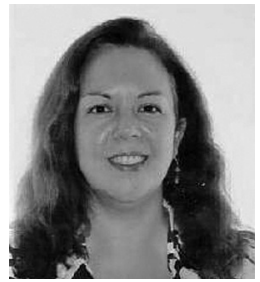

Clara Portela holds a PhD from the European University Institute in Florence (Italy) and an MA from the Free University of Berlin (Germany). She is a professor of Political Science at the University of Valencia (Spain), having previously served at Singapore Management University (Singapore) and the European Union Institute for Security Studies (EUISS) in Paris (France). She received the THESEUS Award for Promising Research on European Integration for her monograph European Union Sanctions and Foreign Policy.

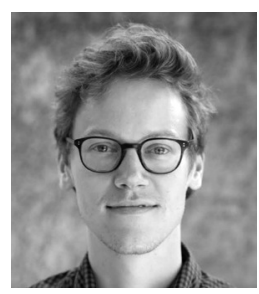

Thijs Van Laer is a researcher working on human rights, conflict, and displacement, with a focus on the Great Lakes region of Africa. He is currently affiliated to the Burundi Human Rights Initiative and is based in Brussels (Belgium). He holds an LLM from the Free University of Brussels (Belgium) and an MA from the Catholic University of Leuven (Belgium). 